\title{
Total Hip Arthroplasty in Patients with Rheumatoid Arthritis
}

\begin{abstract}
Introduction. Total hip arthroplasty has become a successful way of treating the painful and destroyed hip joint in the patient with rheumatoid arthritis( RA).

Materials and Methods. Two hundred and twenty (135 cemented and 85 uncemented) total hip arthroplasties were performed on 180 patients with rheumatoid arthritis. The average age was 48,61 years and the average follow-up was 8,4 years. Clinical evaluation was based on a Harris hip score that showed significant improvement in pain and function preoperatively, compared with pain and function at follow-up. There were two deep infections that required removal of the prosthesis. Four cemented acetabular cups and one cemented femoral component were revised due to aseptic loosening. Three acetabular rings were revised due to aseptic loosening. The relatively inferior results of total hip arthroplasty among RA patients are due not only to fixation method, but also to the poorer bone quality and weakening musculature.

Conclusion. The results in these patients suggest that cementless total hip arthroplasty might become a successful way of treating the destroyed hip joint in the patient with rheumatoid arthritis.
\end{abstract}

\section{KEY WORDS:}

Total arthroplasty, hip, rheumatoid arthritis

DOI: $10.7251 / S M D 1401019 G$

(Scr Med 2014:45:19-22)

\section{Boris Gluščević ${ }^{1}$ Predrag Stošić ${ }^{1}$, Danijel Milosavljević ${ }^{\text {, }}$ Radomir Radivojević ${ }^{1}$, Mirjana Zlatković-Švenda ${ }^{2}$}

\author{
${ }^{1}$ Institute for Orthopedic Surgery \\ "Banjica", Belgrade, Serbia \\ ${ }^{2}$ Institute of rheumatology, \\ University of Belgrade School of \\ Medicine, Serbia
}

\section{Contact address:}

Boris Gluščević

Institut za ortopedsko hirurške

bolesti "Banjica"

Telephone ++381 113675889

1100 o Beograd

Srbija

Submitted: October 23, 2013

Accepted: February 14, 2014

\section{Introduction}

Total hip arthroplasty is probably one of the most successful surgical procedures in patients with rheumatoid arthritis, both in terms of pain relief, and in terms of functional recovery of the patient. Despite the fact that patients with rheumatoid arthritis have lower weight and exhibit lower activity levels, it has been found in literature that there are generally worse results of implanting a total cemented hip endoprosthesis in patients with rheumatoid arthritis, as compared to the population of patients where total endoprothesis is implanted due to primary coxarthrosis. ${ }^{1-4}$ In recent years, number of implantations of cementless hip endoprothesis has increased, but the follow-up period has been relatively short to be able to talk about their benefits with certainty at this point. In this paper, we have presented the results of the primary implantation of cemented and cementless total hip endoprosthesis in patients with rheumatoid arthritis, on the basis of which it may be suggested that cementless endoprosthetic systems have shown a slight advantage over the cemented endoprosthetic systems. ${ }^{4-7}$

\section{Patients and Methods}

Between the year 1992 and 2004 we implanted 220 total endoprothesis in 180 patients who had previously been treated against rheumatoid arthritis and where the primary disease was the main reason for the emergence of arthrosis. In 40 patients, total endoprothesis were implanted in both hips, of which 20 cemented and 12 cementless, while in 8 patients, a cementless prosthesis was implanted in one hip and a cemented prosthesis in the other. 135 cemented prosthesis and 85 cementless prostheses were implanted in total. Of the cementless hip 
endoprosthesis, the anatomic porous ones coated with hydroxyapatite were used, type Kirschner, RCM, Zwey-Miller, Zimmer, whereas the cemented ones were type Charnley with low friction (Lima, Exeter, Bioimpianti, Zimmer). The cementing technique was the first generation. Access was only posterolateral. A single dose of antibiotics was administered intraoperatively. All patients received thromboembolic protection, although it was not the same in different time periods. The average age of patients who had a cemented endoprosthetic implant was 58.2 years (SD15.8 within the 48-78 age range), and in patients with cementless endoprosthetic implants it was 40.4 years (SD 16.0, within the 18-65 age range).

Bone quality of proximal femur at the time of surgery was noted according to Dorr classification. ${ }^{5}$ All patients were monitored in our hospital, and radiographic hip check-up was performed once a year. The average follow-up period for the cemented prosthesis was 10.4 years and for the cementless 6.8 years.

Clinical assessment which referred to pain, function, deformity and range of motion was based on Harris evaluation system. ${ }^{6,7}$ Radiographic assessment was performed at each check-up. Anteroposterior and lateral hip imaging was done as well. Demarcation of the acetabular component was evaluated using the zonal system of De Lee and Charnley. ${ }^{8}$ A Gruen's zonal system was used (10) to assess the stem demarcation. Radiological loosening of the cap was defined as Hodgkinson type 3 or 4 capdemarcation. Loosening of the femoral component was noted in cases when there was more than $5 \mathrm{~mm}$ distal migration or settlement in the anteroposterior image or if there was a fracture of the cement or stem, or if the complete radiolucent line was wider than $2 \mathrm{~mm} .^{9}$

\section{Results}

All the patients had significant clinical improvement with respect to the pain, function and range of motion (Harris hip score, average preoperative 22.4, postoperative 78.5). Preoperatively, 160 patients had severe pain and only 20 a moderate pain. Postoperatively, 150 patients had no pain and 30 of them had mild pain or discomfort in the hip. Due to aseptic loosening, there were four acetabular cemented caps revisions, as well as one of the cemented femoral stem. In 4 acetabular caps there were initial signs of loosening, but no discomfort was felt. Stem subsidence up to $3 \mathrm{~mm}$ was noted in 7 patients, but the follow-up showed no progression. Due to aseptic loosening, 3 acetabular ring revisions were performed and in all cases the stem was stable, well- fixed and intervention on the femoral component was not done. There were two deep infections due to which the endoprosthesis were later removed. In both cases, the cause was methicillinresistant staphylococcus. Of other complications, there was a fracture of the femur below the stem which was resolved by a revision stem, as well as one endoprosthesis luxation, which was immediately repositioned and there were no repeated luxation later. Four patients developed pulmonary embolism in postoperative period, which was adequately resolved. Other complications were the following: development of thrombophlebitis in one patient, and secondary wound healing in three cases.

\section{Discussion}

The choice of implants for total hip arthroplasty remains subject to debate, especially for patients with rheumatoid arthritis. ${ }^{1,10-12}$ Although these patients are usually younger than those with classical coxarthrosis, their bone mass is weaker due to two reasons: the first is considerable activity of the primary disease, the second is medication treatment, which mostly involves the use of non-steroidal antiinflammatory drugs and corticosteroids. ${ }^{3,5}$ It is considered that the results of total hip endoprosthesis implants in patients with rheumatism are worse in comparison with classical coxarthrosis, but cementless endoprosthesis have lately been implanted more often, and so far, the results have been promising. ${ }^{10-14}$ However, it should be noted that the follow-up period was relatively short, and the process of osteointegration, i.e. the process of bone ingrowth into the cementless endoprosthetic system in patients with rheumatoid arthritis is quite debatable. Because of all this, the method of total hip endoprosthesis fixation in patients with rheumatoid arthritis is a significant problem, and a much more complex process than in other indicative cases. Another problem is that the majority of the series presented focuses mainly on one type of implant, so there are no comparative studies which would assist in resolving the controversy. In younger patients with rheumatoid arthritis, similar to other younger patients with primary coxarthrosis, loosening of the acetabular component is also present quite often, which is not the case with the femoral component. We also had greater loosening of the acetabular components than femoral ones in our series. There are different reasons for this. Poss and colleagues ${ }^{5}$ suggest that the loosening of the acetabular component is due to the inability to establish normal acetabulum position in hips with acetabular protrusion. On the other hand, Severt et al. believe that the high degree of cement cap loosening is associated with the implantation of such systems in younger people. ${ }^{11}$ There are also opposing views. ${ }^{3}$

Cementless implants, particularly the ones with hydroxyapatite, seem to produce better results. The only problem with this observation is that the follow-up period is still relatively short, hence the good results shown in different series do not exceed the follow-up period for more than 10 years. In our series, the cementless systems do well, only 3 acetabular ring revisions with no reintervention on the stem. Cemented systems have more loosening, but this applies mainly to the acetabular component 
Comparing the groups of patients with cementless and cemented endoprostheses, we came to the conclusion that better results were shown in the cementless group. Harris hip score was generally similar in these two groups preoperatively, but was significantly better in the cementless group postoperatively. The explanation for this was not found only in the implant type, but it was probably due to the younger age of the cementless group patients. This mainly refers to the acetabular component, while the femoral component does equally well in both cemented and cementless group of patients. Considering all present knowledge, we are close to the view that implanting cementless endoprosthesis to younger patients is appropriate, because there is less technical demand, less patient exposure, and there are fewer consequential revisions, which are currently largely inevitable.

\section{Conclusion}

It should be reminded that every arthroplasty has its lifespan and eventually leads to revision. The longevity of the implant in patients with rheumatoid arthritis, among other things, depends on the bone mass quality. Since rheumatoid arthritis is a disease that leads to the loss of bone tissue, the constant bone remodeling may compromise the bond between the cement and the bone and hence cause loosening, regardless of the quality of the initial cement penetration. Naturally, drugs used to treat rheumatoid arthritis contribute to all this too. Only if the process of bone tissue loss is stopped, a long-term survival of the implant can be expected, and by then, the results with cemented endoprosthetic systems are probably going to be worse. In the meantime, we believe that it is probably more appropriate to implant cementless endoprosthetic systems in young patients with rheumatoid arthritis.

\section{REFERENCES}

1. Chmell MJ, Scott RD, Thomas WH, Sledge CB: Total hip arthroplasty with cement for juvenile rheumatoid arthritis. Results at a minimum of ten years in patients less than thirty years old. $J$ Bone Joint Surg Am,1997; 79:44-52
2. Creighton MG, Callaghan JJ, Olejniczak JP, Johnston RC : Total hip arthroplasty with cement in patients who have rheumatoid arthritis. A minimum ten-year follow-up study. J Bone Joint Surg Am1998; 80:1439-1446

3. Lethimaki MY, Kautiainen H, Lehto MU, Hamalainen MM :Charnley low-friction arthroplasty in rheumatoid arthritis. A survival study up to 20 years. J Arthroplasty,1999; 14:651-661

4. Onsten I, Besjakov J, Carlsson As : Improved radiographic survival of the Charnley prosthesis in rheumatoid arthritis and osteoarthritis. Results of new versus old operative techniques in 402 hips. J Arthroplasty1994; 9:3-8

5. Poss R, Maloney JP, Ewald FC, Thomas WH, Batte NJ, Hartness $\mathrm{C}$, Sledge CB Six to 11-year results of total hip arthroplasty in rheumatoid arthritis. Clin Orthop1984; 182:109-116

6. Dorr LD: Total hip replacement using APR system. Techniques Orthopaed1986; 3:22

7. Harris WH : Traumatic arthritis of the hip after dislocation and acetabular fractures: treatment by mold arthroplasty. An endresult study using a new method of result evaluation. J Bone Joint Surg Am1969; 51:737-755

8. Loehr JF, Munzinger U, Tibesku C: Uncemented total hip arthroplasty in patients with rheumatoid arthritis. Clin Orthop,1999; 366:31-38

9. Gruen TA, McNeice GM, Amstutz HC : `Modes of failure` of cemented stem-type femoral components: a radiographic analysis of loosening. Clin Orthop1979., 141:17-27

10. Lachiewicz PF : Porous-coated total hip arthroplasty in rheumatoid arthritis. J Arthroplasty1994; 9:9-15

11. Severt R, Wood R, Cracchiolo A 3d, Amstutz HC; Long term follow-up of cemented total hip arthroplasty in rheumatoid arthritis. Clin Orthop1991; 265:137-145

12. Unger AS, Inglis AE, Ranawat CS, Johanson NA : Total hip arthroplasty in rheumatoid arthritis. A long-term follow-up study. $\mathrm{J}$ Arthroplasty 1987;2:191-197

13. Garcia Araujo C, Fernandez Gonzalez J, Tonino A: Rheumatoid arthritis and hydroxyapatite-coated hip prostheses: five-year results.1998.

14. Kumar MN, Swann M : Uncemented total hip arthroplasty in young patients with juvenile chronic arthritis. Ann R Coll Surg Engl1998; 80:203-209

\title{
Totalna artroplastika kuka kod pacijenata sa reumatoidnim artritisom
}

\author{
APSTRAKT \\ Uvod. Totalna artroplastika kuka je postala uspešan način lečenja bolnog i uništenog zgloba kuka kod pacijenta sa reumatoidnim \\ artritisom. \\ Ispitanici i metode. Mi smo uradili 220 totalnih artroplastika kuka kod 180 pacijenata sa reumatoidnim artritisom. Prosečna \\ starost pacijenata je bila 48,61 godinu, a prosečno praćenje 8,4 godine. Klinička procena je bila bazirana na Harisovom skoru \\ kuka koji je pokazao značajno poboljšanje, poredeći bol i funkciju preoperativno i postoperativno. Postojale su dve duboke
}


infekcije zbog kojih su endoproteze izvađene. Zbog aseptičnog razlabavljenja urađene su revizije na 4 cementne acetabularne kape i jednoj cementnoj femoralnoj komponenti. Zbog aseptičnog razlabavljenja urađene su 3 revizije acetabularnog ringa.

Zaključak. Kod pacijenata sa reumatoidnim artritisom relativno lošiji rezultati totalne artroplastike kuka postoje ne samo zbog načina fiksacije, već i zbog lošijeg kvaliteta kosti i oslabljene muskulature. Rezultati kod ove grupe pacijenata sugerišu da bescementna totalna artroplastika kuka može postati uspešan način lečenja razorenog zgloba kuka kod pacijenta sa reumatoidnim artritisom.

\section{KLJUČNE REČI:}

Totalna artroplastika, kuk, reumatoidni artritis 